\title{
Is There a Positive Relationship between Law and Economic Growth? A Paradox in China
}

\author{
Rita Yi Man $\mathrm{Li}^{1} \&$ Yi Lut $\mathrm{Li}^{2}$ \\ ${ }^{1}$ Department of Economics and Finance, Hong Kong Shue Yan University, Hong Kong \\ ${ }^{2}$ School of Law, City University of Hong Kong, Hong Kong \\ Correspondence: Rita Yi Man Li, Department of Economics and Finance, Hong Kong Shue Yan University, \\ Hong Kong Shue Yan University , Hong Kong. Tel: 852-2570-7110. E-mail: ritarec1@yahoo.com.hk
}

Received: March 17, 2013 Accepted: April 21, 2013 Online Published: June 28, 2013

doi:10.5539/ass.v9n9p19 URL: http://dx.doi.org/10.5539/ass.v9n9p19

\begin{abstract}
Traditional theorists concur that good legal system has been linked with well-defined property rights, reduction in transactions costs, increase in investments, and economic growth. Nevertheless, China experienced a strong economic growth in spite of a poor legal system. To explore the reasons behind, this research paper reviews the literature about the relationship between law and economic growth from global perspective. After that, this paper tries to locate the reasons on why the formal rules and regulations may not have strong correlation with China's growth. The research concludes that while many people label Guanxi as something negative, Guanxi is an informal system of legal rules from a Western perspective, or de facto, China's style of legal enforcement. Nevertheless, as the Chinese economy grows, transaction costs may become too high if we rely on guanxi and good legal system is needed to ensure a sustainable economic growth.
\end{abstract}

Keywords: economic growth, law, China

\section{Introduction}

In 1978, China implemented economic reform and an Open Door Policy (Mo, 2009; Su, 2009) and has since adopted a series of reform measures that aim to transform China from a centrally planned state to a socialist market economy (Siu \& Liu, 2005; Su, 2009). Consequently, the legal, social, cultural and political environment of China has become chaotic. While the central government decentralised decision-making power to enterprises and gave them greater rights to control, government planning still set the institutional determinants, and political and economic institutions influenced the firms' behaviour and performance. Hence, the performance of Chinese enterprises is determined not only by the environmental factors in the market economy but also by environmental and institutional influences (Siu \& Liu, 2005). While many scholars assert that rule of law and economic development are positively related (North, 1973; North, 1990; Cross, 2001; Xu, 2011), China appears be to an exception to this view. Resulted from free-market-oriented neoclassical economic policies and principles (Das, 2008), China was the ninth fastest growing economy Over the past 25 years (Wu, 2011). The size of its economy now ranks second in the world (twenty years ago, China was ranked 10 $0^{\text {th }}$ ) (Table 1) (Bustelo, 2011). Unfortunately, the Chinese legal system is underdeveloped and laws are loosely enforced. So, is it sufficient to say that the rise of China is a paradoxical mismatch with the traditional concept that there is positive correlation between economic growth and good legal system? This paper first reviews the scholar's view on the relationship between the rule of law and economic development worldwide and in China; this is followed by a discussion of traditional Chinese culture, focusing on Guanxi, an informal system of legal rules from a Western perspective or de facto, China's style of legal enforcement. This paper concludes that the western style rule of law may not be a major determining factor in a country's initial economic development in a relatively simple society where informal institutions such as guanxi are sufficient for playing the legal role. Nevertheless, formal written rule of law will certainly become more important as transaction costs grow and collectivism fades in China. 
Table 1. GDP in 16 countries (Bustelo, 2011)

\begin{tabular}{lrrrr}
\hline Country & GDP in 1990 & Range in 1990 & GDP in 2010 & Range in 2010 \\
\hline USA & 5.800 .525 & 1 & 14.657 .800 & 1 \\
China & 390.278 & 10 & 5.878 .257 & 2 \\
Japan & 3.058 .038 & 2 & 5.458 .872 & 3 \\
Germany & 1.547 .026 & 3 & 3.315 .643 & 4 \\
France & 1.248 .563 & 4 & 2.582 .527 & 5 \\
United Kingdom & 1.017 .792 & 6 & 2.247 .455 & 6 \\
Brazil & 507.784 & 9 & 2.090 .314 & 7 \\
Italy & 1.135 .543 & 5 & 2.055 .114 & 8 \\
Canada & 582.735 & 7 & 1.574 .051 & 9 \\
India & 325.928 & 12 & 1.537 .966 & 10 \\
Russia & $\mathrm{SD}$ & - & 1.465 .079 & 11 \\
Spain & 8 & 1.409 .946 & 12 \\
Australia & 520.709 & 11 & 1.235 .539 & 13 \\
Mexico & 327.526 & 14 & 1.039 .121 & 14 \\
South Korea & 287.803 & 15 & 1.007 .084 & 15 \\
The Netherlands & 270.405 & 13 & & - \\
\hline
\end{tabular}

\section{A Scholar's View of the Relationship between Rule of Law and Economic Development: An International Perspective}

After World War II, the revival of Western economies led to an increase in popularity for research in economics and law. In 1960, Ronald Coase asserted that the uncertainty of property rights would lead to high transaction costs and consequently hinder economic development (Coase, 1960). North, in 1973, proposed the Rights Hypothesis, claiming that the enforcement of contractual rights and security rights is necessary to economic development (North, 1973), e.g. it determines both the rate and direction of investment (Carden \& Hall, 2010). When law is nonexistent or weak, the enforcement of property contract rights depends on threat and sometimes violence. The hidden costs of these substitutes include a bias against new firms, which have no reputation to demonstrate their reliability to their clients (Posner, 1998). As mentioned by Martin (2012), "when the rules of the game are not stable, competition hindered." The World Bank's researchers, in the 1997 World Bank Report, affirmed that countries with "predictable methods of changing law, secure property rights, and a strong judiciary saw higher investment and growth than countries lacking these institutions" (Peerenboom, 2002). The empirical evidence supports Peerenboom's aforesaid proposition. Research focused on the relationship between rule of law and economic development performed by the World Bank and the US's CIA found that there is a proportional increase in rule of law and social wealth. $\mathrm{Xu}$ (2011) found that the likelihood of a high rule of law country enjoying higher income is $29 / 34(85.29 \%)$, a finding that coincides with other scholarly views (Bashir, 2002; Kumssa \& Mbeche, 2004; Krever, 2011; Osman, Alexiou, \& Tsaliki, 2011) (one exceptional case was (Osman et al., 2011)). As concluded by The Economist (2008), the general view of scholarship is that "rule of law has become the motherhood and apple pie of development economics." 
Table 2. The relationship between rule of law and economic growth $(\mathrm{Xu}, 2011)$

\begin{tabular}{llllll}
\hline & $\begin{array}{l}\text { Low income } \\
\text { countries }\end{array}$ & $\begin{array}{l}\text { Low middle } \\
\text { income countries }\end{array}$ & $\begin{array}{l}\text { Upper middle } \\
\text { income countries }\end{array}$ & $\begin{array}{l}\text { High income } \\
\text { countries }\end{array}$ & Total \\
\hline $\begin{array}{l}\text { Low rule of law } \\
\text { countries }\end{array}$ & 19 & 10 & 2 & 2 & 33 \\
$\begin{array}{l}\text { Lower middle rule of } \\
\text { law countries }\end{array}$ & 28 & 31 & 17 & 3 & 79 \\
$\begin{array}{l}\text { Upper middle rule of } \\
\text { law countries }\end{array}$ & 1 & 15 & 18 & 26 & 60 \\
$\begin{array}{l}\text { High rule of law } \\
\text { countries }\end{array}$ & 1 & 1 & 3 & 29 & 34 \\
Total & 49 & 57 & 40 & 60 & 206 \\
\hline
\end{tabular}

Table 3. A literature review on the relationship between economic growth and rule of law

\begin{tabular}{|c|c|c|}
\hline Authors & City, country & The relationship between law and economic growth \\
\hline (Park & 60 countries & Stronger intellectual protection improves economic growth as there will be \\
\hline Ginarte,1997) & & more investment opportunities, research and development activities. \\
\hline $\begin{array}{l}\text { (Tavares, } \\
\text { 2004) }\end{array}$ & Portugal & $\begin{array}{l}\text { Institutions affect economic growth as far as they affect transaction costs and } \\
\text { the production possibility frontiers. While more than half of the ten } \\
\text { institutional indices that have the strong impact on economic growth, legal } \\
\text { area is the most promising area among all these institution factors. }\end{array}$ \\
\hline $\begin{array}{l}\text { (Adbdoul, } \\
2008 \text { ) }\end{array}$ & 123 countries & $\begin{array}{l}\text { An improvement in the individual quality of democratic property rights and } \\
\text { regulatory institutions is favourable for sustainable economic growth. } \\
\text { Economic growth requires the presence of good institutions which gurantee } \\
\text { relatively low costs for investments. }\end{array}$ \\
\hline (Badun, 2006) & Croatia & $\begin{array}{l}\text { If the courts fail to enforce contract, fail to protect rights of property, and fail } \\
\text { to resolve disputes in good time, the motivation for investment and } \\
\text { innovation will be reduced, incentives for productive activities will be } \\
\text { lowered, and rent-seeking activities will be enlarged. Similarly, failure to } \\
\text { respect the rule of law brings a fall in respect for the justice system and the } \\
\text { confidence in justice which in turn affect the level of investment. In Croatia, } \\
\text { therefore, the rule of law is an important factor which affects the economic } \\
\text { growth. }\end{array}$ \\
\hline
\end{tabular}

(Cross, 2001) Not specific The neoclassical economic model concedes that levels of economic development should steadily converge among nations and ultimately equalizing wealth independent of law. The new institutional economics suggests that institutional capital may be a more important determinant of economic development than physical capital, financial capital, technological capital or human capital.

(North, 1990) Not specific The existence of a legal system which protects property and contract rights is a precondition for economic development as the costs will be unacceptably high without such a system. The lack of certainty about who will receive benefit from investments and/or transactions will inhibit such transactions. 


\begin{tabular}{|c|c|c|}
\hline Authors & City, country & The relationship between law and economic growth \\
\hline$(\mathrm{Xu}, 2011)$ & $\begin{array}{l}\text { Low, middle } \\
\text { and high } \\
\text { income } \\
\text { countries }\end{array}$ & $\begin{array}{l}\text { Rule of law embodies and encourages a just society, also enhances economic } \\
\text { growth. Therefore, a higher rule of law, the richer the nation. }\end{array}$ \\
\hline $\begin{array}{l}\text { (Posner, } \\
1998)\end{array}$ & Not specific & $\begin{array}{l}\text { When law is weak or nonexistent, enforcement of property rights depends on } \\
\text { threat and violence. The hidden costs of these substitutes are bias against } \\
\text { new firms with no reputation to show their clients their level of reliability. } \\
\text { Therefore, a small expenditure on law reform raises the economic growth } \\
\text { rate. }\end{array}$ \\
\hline $\begin{array}{l}\text { (Krasniqi, } \\
2010)\end{array}$ & Kosovo & $\begin{array}{l}\text { Informal economy (hidden and illegal activities) creates inaccurate official } \\
\text { data such as level of income and unemployment rate, making the economic } \\
\text { policy ineffective. }\end{array}$ \\
\hline (Bashir, 2002) & $\begin{array}{l}\text { Islamic } \\
\text { countries }\end{array}$ & $\begin{array}{l}\text { When property rights are ill defined, contracts become hard to enforce, fraud } \\
\text { and corruption may result. Well-defined and effective property rights are } \\
\text { pre-condition for economic growth. The private control over assets and the } \\
\text { ability to reap the profits from these assets become the major motivations for } \\
\text { production and investment. Furthermore, enforcing contractual agreements } \\
\text { provide the economic agents with the incentives to use resources efficiently } \\
\text { and effectively. }\end{array}$ \\
\hline $\begin{array}{l}\text { (Krever, } \\
2011)\end{array}$ & $\begin{array}{l}\text { Developing } \\
\text { countries }\end{array}$ & $\begin{array}{l}\text { When private property rights are not protected, contracts are not enforced } \\
\text { predictably, or judicial enforcement is unreliable, the private sector does not } \\
\text { have confidence that the state will enforce the rules of the game. Investment } \\
\text { suffers as entrepreneurs will not commit resources in highly volatile and } \\
\text { uncertain environment. Growth and investment also suffer as a result. The } \\
\text { rule of law is essential as it facilitates the private sector to function and } \\
\text { creates the incentive to which economic agents respond. }\end{array}$ \\
\hline $\begin{array}{l}\text { (Kumssa \& } \\
\text { Mbeche, } \\
\text { 2004) }\end{array}$ & $\begin{array}{l}\text { African } \\
\text { countries }\end{array}$ & $\begin{array}{l}\text { By providing a conducive environment for implementation and sustainable } \\
\text { development programmes, well-functioning institutions can promote } \\
\text { economic growth and reduce poverty in Africa. }\end{array}$ \\
\hline $\begin{array}{l}\text { (Swaleheen \& } \\
\text { Stansel, 2007) }\end{array}$ & $\begin{array}{l}60 \quad \text { panel } \\
\text { countries }\end{array}$ & $\begin{array}{l}\text { For countries with low economic freedom, corruption hampers economic } \\
\text { growth. Countries with high economic freedom, corruption increases } \\
\text { economic growth. }\end{array}$ \\
\hline $\begin{array}{l}(\text { Beck } \& \\
\text { Levine, 2005) }\end{array}$ & $\begin{array}{l}\text { France, } \\
\text { Germany }\end{array}$ & $\begin{array}{l}\text { In countries where legal system enforces property rights, protect legal rights } \\
\text { of the investors and support contractual arrangements, savers are more } \\
\text { willing to provide source of finance to firms which enhances the finance } \\
\text { market development. }\end{array}$ \\
\hline $\begin{array}{l}\text { (Osman et al., } \\
\text { 2011) }\end{array}$ & $\begin{array}{l}27 \quad \text { African } \\
\text { countries }\end{array}$ & $\begin{array}{l}\text { Corruption, which is often regarded as a signal of poor legal environment, } \\
\text { was found to grease the wheel of economic development in African } \\
\text { countries. }\end{array}$ \\
\hline
\end{tabular}




\section{China as an Exception - The Informal Rules That Are Supplementary to the Formal Written Rule of Law Leads the Dragon to the Road of Revival}

Between 1995 and 2008, China's average annual growth rate for GDP was 9.64\%, which was over twice the world's average (4.56\%). China was also the ninth-fastest growing economy among the 183 economies in a study conducted by $\mathrm{Wu}$ (2011). Nevertheless, in sharp contrast to this fast growing economy is China's underdeveloped legal system, which is vulnerable to political pressure, the poor enforcement of legal rules and weak and poorly defined property rights (Allen, Qian, \& Qian, 2005; Braendle, Gasser, \& Noll, 2005; Davison \& Ou, 2008; Ji, 2009; Landry, Tong, \& Shen, 2009; Lu \& Yang, 2009; Yueh, 2010; Wu, 2011; Xu, 2011). For example, corruption is one of China's major problems (China ranks 75 out of 182 countries for the level of corruption in 2011) (Braendle et al., 2005; Transparency International, 2011) along with violation of intellectual property rights (Chow, 1997). Each year, 15 million illegal mobile phones are distributed worldwide from Shenzhen, and illegal mobile phones occupy $1 / 3$ of the market: Chinese manufacturers change one or two letters of the branded product and turn it into their own product (Hu, 2008). China has also been criticised for being the world's major culprit in intellectual property infringement; it accounts for nearly $2 / 3$ of counterfeit goods, including motorcycles, movies, music CDs, DVDs, designer handbags and so on, with an estimated 512 million counterfeit products having been sold worldwide (Priest, 2006 ). Therefore, many scholars note that a strong legal system is not a precondition for economic growth in China (Allen et al., 2005; Clarke, Murrell, \& Whiting, 2006; Lu \& Yang, 2009), or they predict that law will simply develop after economic growth (Chen, 2003; Shen \& Wang, 2009), despite the many scholars who believe that well-developed legal systems favour economic growth (Potter, 1999; Lam \& Chen, 2004; Yu, 2009).

Table 4. Scholar's views on the relationship between law and economic growth in China

\begin{tabular}{ll}
\hline Authors & The relationship between law and economic growth \\
\hline (Lam \& Zonggui, & A concrete, objective set of regulations assists long-term economic development by \\
increasing the level of certainty. Greater certainty in law ultimately attracts more foreign \\
investment and promotes economic growth. \\
Empirical data shows that there is a close relationship between the growth rate of fixed \\
asset investment and GDP growth rate. As property rights is important in attracting private \\
investment and the business organization law paves the way for level playing field \\
between different enterprises, law is important in economic development. \\
Laws which govern the foreign business activities make direct investment possible; they \\
also play an essential role in economic growth. \\
Clearer property rights enhances economic growth \\
The Law of the People's Republic of China on Chinese-Foreign Equity Joint Ventures, the \\
Law of the People's Republic of China on Foreign-Capital Enterprises, the Law of the \\
People's Republic of China on Chinese-Foreign Contractual Joint Ventures, together with \\
the Regulations on Special Economic Zones of Guangdong Province promulgated in 1980 \\
created favorable environments for foreign capital to flood into China. \\
The present constitution, as the basic of the contemporary China, played a positive role in \\
stimulating economic development \\
An effective legal regulatory framework allows a market to produce in its maximum \\
efficiency. As the market development goes further, the bureaucratic system must strive to \\
transform its regulation towards the rule of law and China is developing its legal system \\
to improve the certainty and market economy development.
\end{tabular}


Authors The relationship between law and economic growth

(Allen et al., 2005) Due to the population, size of the economy and potential markets, China has a competitive advantage in attracting foreign investment over many other smaller developing countries that also have poor financial and/or legal systems. Investors from Hong Kong and Taiwan are willing to bear the extra risk to invest in Chinese firms just to enter its markets for prospective long-term profits because: first, the informal mechanisms based on implicit contractual agreements and reputation ensure that firms the effective corporate governance and second, they know where to obtain reliable information about the informal mechanisms as well as political uncertainties.

(Lu \& Yang, 2009) Using Chinese data in the 1990s, enhanced legal system suppresses private investment and has no impact on financial depth even though it increases the private share of bank credits and bank competition. These findings evidence the leakage effect which moves financial resources from the privileged state sector to the private sector. Furthermore, enhanced legal system does not have a significant impact on the average GDP growth rate. It is concluded that the smooth functioning of the legal system requires other institutions to complement.

(Clarke et al., 2006) China experienced rapid growth during the reform period, however, legal development started to catch up only in the $90 \mathrm{~s}$.

(Shen \& Wang, As GDP grows, people's acceptance of the formal legal institutions becomes stronger.

(Chen, 2003)

China's recent experience largely follows cash-then-law correlation. Capital markets are the most influential factors to the formation of a powerful political constituency and thus more aggressive legal change.

(Peerenboom, The rule of law and economic development are closely related, and tend to mutually 2007). reinforcing.

\subsection{The Formal Written Rule of Law Is NOT Promoted in the Traditional Chinese Culture}

The traditional Chinese culture does not promote the usage of written laws, rules and regulations in dispute resolution. Black and white written rules, in the eyes of the masses and leaders, are tools used by the ruler to control the social order (Chen, 2003). Because these laws have predominantly been linked with unpleasant historical memories, both in the public's view and in reality, the Chinese generally view them with fear and aversion (Braendle et al., 2005). A Chinese proverb even says "Do not visit the bureau when one is alive; do not visit hell when one is dead." (Sheng-buru-guanmen, si-buru-diyu.) The Chinese equate seeking resolution from government (or, in the present sense, the court) to being put into hell after death. Conspicuously, formal rules and regulations are not the first option for people trying to solve conflicts or relationship issues. Additionally, the traditional legal system seldom provides individuals with instruments and guidelines for addressing private disputes.

In addition to the notorious traditional image of the law, Chinese culture also drives the general public away from the law. In sharp contrast to individualistic life in the Western world, China is a collectivist society with low degree of individualism (Jia \& Kvan, 2005). Collective culture values shape the expectations of individual's behaviour (Jia, Rowlinson, Kvan, \& Yip, 2009). One of the predominant features of collectivism is its de-emphasis of the rule of law (Collier, 2002). Most likely, people believe that seeking the bureaucracy's involvement hampers relationships among parties, which contravenes the concept of hexie (peace and harmony).

Indeed, the rule and use of law to resolve conflicts and seek resolution is a Western concept, and the transplant of western rule of law to the Chinese culture is tedious and difficult (Chen, 2000). Therefore, even today, courts are not the resource for concerns, as illustrated by business practice: among the approximately five million enterprises in China, only 4\% have regular legal advisers (Allen et al., 2005). So, is there any substitute or 
complement to the rule of law that facilitates the economic development of China?

\subsection{Alternative Enforcement and Punishment System}

The high enforcement cost under the American legal system suggests that informal alternatives to legal regulation may be more efficient than competitive markets based on law (Jones, 1994; Chow, 1997). The solution to an ineffective legal system lies in a traditional culture with regard to its possible outcomes on society (Braendle et al., 2005). Although the written form of rule of law is weak in China, Guanxi, an informal legal enforcement system, is de facto China's style of law in a simple collectivistic society.

\subsubsection{Guanxi as an Alternative Reward and Punishment System: China-Style Rule of Law}

Traditional Chinese culture rejects individualism. What people emphasise is Guanxi, or in some scholar's definition, "friendship with implications of continued exchange of favors" (Pye, 1992). In Chinese society, guanxi is a type of human capital, and having guanxi is like having a reputation conveyed by a college degree and knowledge of which friend would be helpful when needed (Chow, 1997). Guanxi identifies the importance of the collective in social interaction in China (Law \& Jones, 2009). The Chinese believe that the person who is encountered for the first time cannot be trusted (Luo \& Chen, 1996); the Chinese usually treat strangers with caution (Wang, Huang, Chu, \& Wang, 2010) and continue to assess a stranger until he is proved to be trustworthy by daily experience (Luo \& Chen, 1996). In effect, who you know is more important then what you know (Wong, 2007). Unlike the foreigners who do business before they dine together, the Chinese usually dine before doing business together (Zolkiewski \& Feng, 2009). According to Victor Fund, the Chairman of Prudential Asia (1994), "if you are being considered for a new partnership, a personal reference from a respected member of the Chinese business community is worth more than any amount of money you could throw on the table" (Kraar, 1994). In this sense, guanxi is an important asset for both individuals and firms. Nevertheless, guanxi can also be a major hurdle when doing business or when the best candidate in the job market is not selected because he lacks an interpersonal network. Therefore, many people believe that guanxi may be detrimental to society.

Yet, guanxi serves as enforcement. For example, if a company or an individual has always fulfilled its/his promise, it/he will be considered to be trustworthy and people will trade with it/him again (Luo \& Chen, 1996). Guanxi can also ruin trades: when someone fails to follow the rule of reciprocity and equity, he will be labelled as untrustworthy and no one will trade with him again (Luo \& Chen, 1996). More importantly, social guanxi is transferrable (Tsang, 1998). A breach of faith against one person will be harmful to his business with others because the victim will depict him as evil to his friends and family. This negative influence could be far-reaching if the person who was betrayed has a broad guanxi network. Therefore, no one dares to go back on his word or to make money at another's expense. Any misbehaviour will hamper the guanxi network. In this sense, guanxi could be treated as an alternative reward and punishment system, a type of "unwritten law" (Braendle et al., 2005) that serves as a surrogate market system due to ill-defined property rights, economic roles, and a restricted flow of information (Braendle et al., 2005); guanxi has become the engine of growth for SMEs in China (Ji, 2009).

\subsubsection{Other Alternatives}

Aside from guanxi, the Chinese family concept also guarantees the fulfilment of promises. Family is the centre of life, and family awareness is more salient than individuality (Braendle et al., 2005). People treasure family life and relationships. Generally, no one would run away to avoid fulfilling an agreement because they would feel immoral and guilty about leaving their family behind; the family could suffer a loss of face for a misbehaviour that harms a third party. Even if someone abandoned his family, the victim is not abandoned; the family members would try their very best to implement the agreement or, at least, to pay compensation. They would likely feel ashamed for their family member's dishonesty; his dishonesty is an insult not only to himself but also to them. Executing the agreement is the best way for the family to save face.

\section{Western Style Rule of Law Is a Must in Modern China}

Guanxi occupies an important position in governing behaviour in modern China. Nevertheless, as the economy becomes increasingly complex due to marketisation, legal reform is playing a greater role in the decentralised market (Yueh, 2010). The insufficiency of informal enforcement is also clearly depicted in the worsening of the environment. The increasingly frequent appearance of serious risk foods such as dyed bread buns, fake infant milk powder formula and poisoned pork over the past 10 years (Clarke, 2003; Balzano, 2012) demonstrate that guanxi is insufficient to monitor all aspects of people's behaviour (Clarke, 2003). Conspicuously, the adoption of the rule of law is the ultimate solution to the problems arising from an increasingly complex society. 


\subsection{Collectivism - Which Offers Housing-Keeping Rules - Is Fading}

Traditional Chinese culture is being challenged by the "cultural invasion" of the West. Under the Open Door Policy, communications between China and the rest of the world have become more frequent. Western ideologies have been spread over China via various channels, e.g., education, media, etc. "Bourgeois individualism" and the "ethic of self-gain" has begun to influence the Chinese, especially the young generations (Yang, 1994). Traditional guiding principles such as guanxi and the family concept are fading. More importantly, under the "One Child Policy", each couple can raise only one child. The children born under this policy have become the "little emperor" of their family. This generation is relatively self-centred and individualistic. Not surprisingly, the mechanisms guiding relationships are, and continue to be, less influential. Formal written legal rule is the best tool to fill the gap left by the fading of collectivism.

\subsubsection{Guanxi Cannot Address the Needs of an Increasingly Complex Society}

The effectiveness of traditional values such as guanxi for regulating human behaviours largely varies with the degree of mobility of the citizens. If the entire family can move from one place to another easily, no one cares about the undesirable consequences of a breach of faith. Somebody can turn over a new leaf in a place far away from his hometown, and no victims will know where he is and his new neighbours will not know his history. The consequences resulting from prior misconduct can hardly affect him. Therefore, the effectiveness of traditional values relies on a basic requirement: the low mobility of the citizens.

China has experienced rapid development since 1995. The mobility of citizens is unprecedentedly high; for example, the hukou (household registration) system no longer accurately reflects the population distribution. The increasing flexibility of the hukou system has led to an extraordinary increase in the intra- and inter-provincial migration. The fifth national census (2000) counted 121.07 million long-term nationwide migrants. Millions of people who registered in rural areas have already moved to urban areas (Landry et al., 2009). A study conducted in 2002 showed that these urban "movers" amounted to $20 \%$ of a sample taken in Beijing (Landry \& Shen, 2005). Moreover, with the speedy construction of infrastructure, e.g., the length of railways and the length of highways increased by $19.9 \%$ and 233.6\%, respectively, from 1995 to 2009 (Table 5) (National Bureau of Statistics of China, 2010). It is reasonable to predict that the mobility of citizens will further increase in the future. In other words, the efficacy of traditional values as an informal ruling system is diminishing.

Table 5. Transport rules of China from 1990 to 2009 (National Bureau of Statistics of China, 2010)

\begin{tabular}{|c|c|c|c|c|c|}
\hline Item & 1990 & 1995 & 2000 & 2008 & 2009 \\
\hline Length of National Railways in Operation (km) & 53378 & 54616 & 58656 & 63975 & 65491 \\
\hline Double-Tracking Length (km) & 13024 & 16909 & 21408 & 26599 & 28682 \\
\hline Proportion $(\%)$ & 24.4 & 31.0 & 36.5 & 41.6 & 43.8 \\
\hline Automatic Blocking Length $(\mathrm{km})$ & 10370 & 12910 & 18318 & 28100 & 31619 \\
\hline Length of Highways (km) & 1028348 & 1157009 & 1402698 & 3730164 & 3860823 \\
\hline Expressway and Class I to IV Highways & 741040 & 910754 & 1216013 & 2778521 & 3056265 \\
\hline Proportion $(\%)$ & 72.1 & 78.7 & 86.7 & 74.5 & 79.2 \\
\hline Length of Navigable Inland Waterways & 109192 & 110562 & 119325 & 122763 & 123683 \\
\hline Standard Waterways (km) & & 56587 & 61367 & 61093 & 61546 \\
\hline Proportion (\%) & & 51.2 & 51.4 & 49.8 & 49.8 \\
\hline
\end{tabular}

Furthermore, the transaction costs of guanxi in a simple village (for example, a village with 10 people) are quite low. Nevertheless, the costs become high when the business expands to a large city where building up relationships with the many people becomes an impossible task. The popularity of the internet further complicates the picture: buyers may come from Guangzhou while the sellers are in Ha'erbin. This type of trading is beyond the range of guanxi. Secondly, companies in the Western World expand their business to China, so as the China ones expand their business to Africa and the West (Tuuli \& Rowlison, 2009) where guanxi network fails to cover these activities. Furthermore, the high transaction costs to overcome the existing problem in legal system with the help from guanxi network may become another hurdle, apart from input driven suggested by Troilo and Sun (2010), that restrain economic growth in the future. 


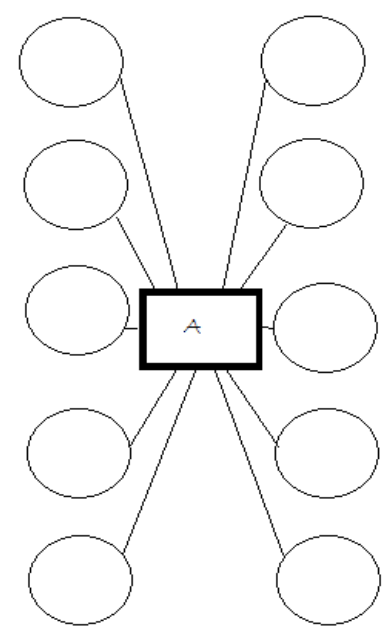

1 layer only

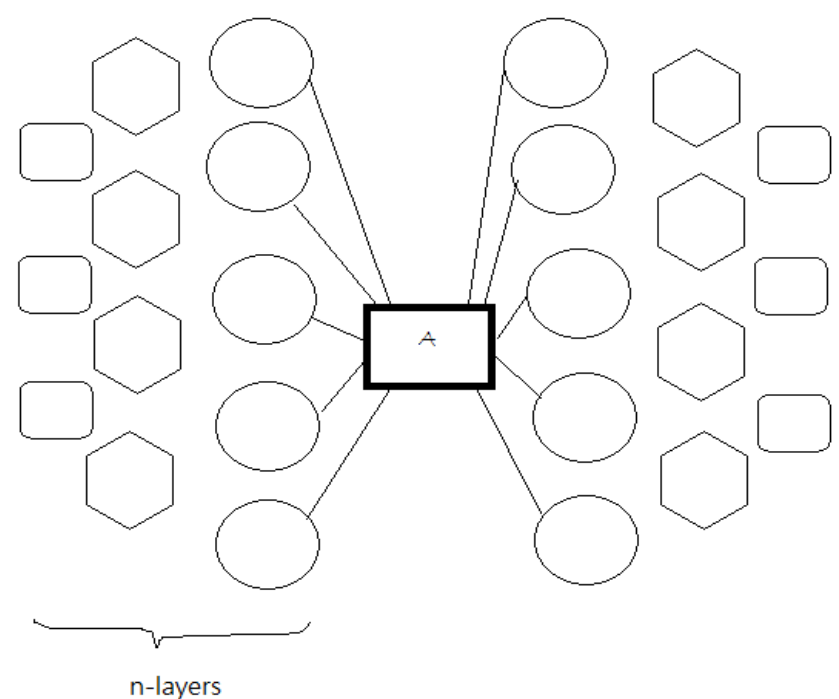

Figure 1. Simple society \& complex society

More importantly, traditional values have fundamental drawbacks: those who are not in the guanxi network or are not family members may face difficulties in maintaining and expanding their business. In a recent interview conducted jointly by the Hurun Report and the Bank of China, 25\% of the billionaires claimed that the reason for investing overseas was that they were afraid that the government officials with whom they do not have good guanxi may prosecute them by using loopholes in the legal system (Mingpao, 2011). Apparently, constructing a fair legal system is a must to restore the confidence of local and foreign investors.

In addition, guanxi may be utilised by unscrupulous people to operate a business at the expense of the country's and the public's long-term interest. For instance, factory owners could evade punishment when discharging sewage that does not meet the governmental standard by asking for help from officials with whom they have good guanxi. By some estimates, China needs 2\% - 5\% GDP annually to clean up the environment (North, 1973). Obviously, relying only upon traditional values such as guanxi cannot ensure sustainable economic development. Instead, the rule of law may be a better tool for this purpose.

\section{Conclusion}

Traditional values explain why China is an exception to the principle that economic development must be the result of a good legal system. Nonetheless, due to the increasing complexity of China's society and business world and due to the fundamental defects of traditional values as an informal ruling system, perfecting the legal system is the only way to guarantee sustainable economic development for China.

\section{References}

Adbdoul, G. M. (2008). Sustained Economic Growth: Do Institutions Matter, Which One Prevails? Cato Journal, 28(3), 385-420.

Allen, F., Qian, J., \& Qian, M. (2005). Law, Finance, and Economic Growth in China. Journal of Financial Economics, 77(1), 57-116. http://dx.doi.org/10.1016/j.jfineco.2004.06.010

Badun, M. (2006). The Quality of Governance and Economic Growth in Croatia. Occasional Paper Series Institute of Public Finance, 29, 5-24.

Balzano, J. (2012). China's Food Safety Law: Administrative Innovation and Institutional Design in Comparative Perspective. Asian-Pacific Law \& Policy Journal, 13(2), 23-80.

Bashir, A. H. M. (2002). Property Rights, Institutions and Economic Development: An Islamic Perspective. Humanomics, 18(3), 75-91. http://dx.doi.org/10.1108/eb018877

Beck, T., \& Levine, R. (2005). Legal Institutions and Financial Development. Handbook of New Institutional Economics. C. Menard \& M. Shirley, Springer. http://dx.doi.org/10.1007/0-387-25092-1_12

Braendle, U. C., Gasser, T., \& Noll, J. (2005). Corporate Governance in China - Is Economic Growth Potential Hindered by Guanxi. Business and Society Review, 110(4), 389-405. http://dx.doi.org/10.1111/j.0045-3609.2005.00022.x 
Bustelo, P. (2011). La UE ante el auge económico de Asia-Pacífico (DT). Retrieved December 1, 2012, from $\mathrm{http} / / / \mathrm{www}$. realinstitutoelcano.org/wps/portal/rielcano/contenido?WCM_GLOBAL_CONTEXT=/elcano/el cano_es/zonas_es/dt15-2011

Carden, A., \& Hall, J. (2010). Why Are Some Place Rich While Others Are Poor? The Institutional Necessity of Economic Freedom Economic Affairs, 30(1), 48-54. http://dx.doi.org/10.1111/j.1468-0270.2009.01973.x

Chen, A. H. Y. (2000). Towards a Legal Enlightenment: Discussions in Contemporary China on the Rule of Law. UCLA Pacific Basin Law Journal, 17, 125-165.

Chen, C. H., \& Wu, H. L. (2005). Determinants of Regional Growth Disparity in China's Transitional Economy. Journal of Economic Studies, 32(5), 406-419. http://dx.doi.org/10.1108/01443580510622397

Chen, Z. (2003). Capital Markets and Legal Development: the China Case. China Economic Review, 14(4), 451-472. http://dx.doi.org/10.1016/j.chieco.2003.09.016

Chow, G. C. (1997). Challenges of China's Economic System for Economic Theory. The American Economic Review, 87(2), 321-327.

Clarke, D., Murrell, P., \& Whiting, S. H. (2006). The Role of Law in China's Economic Development. George Washington University Law School Public Law and Legal Theory Working Paper 187.

Clarke, D. C. (2003). Economic Development and the Rights Hypothesis: The China Problem. American Journal of Comparative Law, 51, 89-111. http://dx.doi.org/10.2307/3649141

Coase, R. H. (1960). The Problem of Social Costs. Journal of Law and Economics, 3, 1-44. http://dx.doi.org/10.1086/466560

Collier, M. W. (2002). Explaining Corruption: An Institutional Choice Approach. Crime, Law \& Social Change, 38, 1-32. http://dx.doi.org/10.1023/A:1019802614530

Cross, F. B. (2001). Law and Economic Growth. Texas Law Review, 80(7), 1737-1776.

Das, D. K. (2008). Rapid Growth in China and the Asian Economies: Some Dtylised Free Market Policy Inferences. Economic Affairs, 28(3), 57-61. http://dx.doi.org/10.1111/j.1468-0270.2008.00846.x

Davison, R. T., \& Ou, C. X. (2008). Guanxi, Knowledge and Online Intermediaries in China. Chinese Management Studies, 2(4), 281-302. http://dx.doi.org/10.1108/17506140810910935

$\mathrm{Hu}, \mathrm{K}$. (2008). Made in China: the Cultural Logic of OEMs and the Manufacture of Low-cost Technology. Inter-Asia Cultural Studies, 9(1), 27-42. http://dx.doi.org/10.1080/14649370701789617

Ji, C. (2009). Chinese Informal Financial Systems and Economic Growth - A Case Study of China's Small and Medium Enterprises. Policy Research Institute, Ministry of Finance, Japan, Public Policy Review, 5(1), 63-88.

Jia, A. Y., Rowlinson, S., Kvan, T., \& Yip, B. (2009). Burnout Among Hong Kong Chinese Architecture Students: the Paradoxical Effect of Confucian Conformity Values. Constructon Management and Economics, 27(3), 287-298. http://dx.doi.org/10.1080/01446190902736296

Jia, Y., \& Kvan, T. (2005). Srudents' Learning Styles and Their Correlation with Performance in Architectural Design Studio. Design Studies, 26, 19-34. http://dx.doi.org/10.1016/j.destud.2004.06.004

Jiang, B., \& Prater, E. (2002). Distribution and Logistic Development in China: the Revolution Has Begun. International Journal of Physical Distribution \& Logistics Management, 32(9), 783-798. http://dx.doi.org/10.1108/09600030210452459

Jones, C. A. G. (1994). Capitalism, Globalization and Rule of Law: an Alternative Trajectory of Legal Change in China. Social \& Legal Studies, 3(2), 195-221. http://dx.doi.org/10.1177/096466399400300201

Kraar, L. (1994). The Overseas Chinese: Lessons from the World's Most Dynamic Capitalist. Fortune, 91-114.

Krasniqi, A. (2010). Impact of the Legislation in Informal Economy of South - Eastern European countries With Particular Focus in Kosovo. Journal of Advanced Research in Law and Economics, I(2(2)), 130-136.

Krever, T. (2011). The Legal Turn in Late Development Theory: The Rule of Law and the World Bank's Development Model. Harvard International Law Journal, 52, 288-319.

Kumssa, A., \& Mbeche, I. M. (2004). The Role of Institutions in the Development Process of African Countries. International Journal of Social Economics, 31(9), 840-854. http://dx.doi.org/10.1108/03068290410550638

Lam, Y. T., \& Chen, Z. (2004). The development of the construction legal system in China. Construction 
Management and Economics, 22, 347-356. http://dx.doi.org/10.1080/0144619032000122177

Lam, Y. T., \& Zonggui, C. (2004 ). The Development of the Construction Legal System in China. Construction Management and Economics, 22(4), 347-356. http://dx.doi.org/10.1080/0144619032000122177

Landry, P. F., \& Shen, M. (2005). Reaching Migrants in Survey Research: The Use of the Global Positioning System to Reduce Coverage Bias in China. Political Analysis, 13(1), 1-22. http://dx.doi.org/10.1093/pan/mpi001

Landry, P. F., Tong, Y., \& Shen, M. (2009). Introduction: Markets, Courts and Leninism. The China Review, 9(1), $1-16$.

Law, S. F., \& Jones, S. (2009). A Guanxi Model of Human Resource Management. Chinese Management Studies, 3(4), 313-327. http://dx.doi.org/10.1108/17506140911007486

Lu, S. F., \& Yang, Y. (2009). The Effectiveness of Law, Financial Development, and Economic Growth in an Economy of Financial Repression: Evidence from China. World Development, 37(4), 763-777. http://dx.doi.org/10.1016/j.worlddev.2008.07.018

Luo, Y., \& Chen, M. (1996). Managerial Implications of Guanxi-based Business Strategies. Journal of International Management, 2(4), 193-216

Martin, E. (2012). On One Forgotten Cause of the Arab Spring: the Lack of Economic Freedom. Economic Affairs, 32(3), 94-96. http://dx.doi.org/10.1111/j.1468-0270.2012.02180.x

Mingpao. (2011). Billionaires Decide to Leave. Retrieved October 6, 2012, from http://hk.news.yahoo.com/\%E8\%BF\%91\%E5\%8D\%8A\%E5\%8D\%83\%E8\%90\%AC\%E5\%AF\%8C\%E8\% B1\%AA\%E6\%93\%AC\%E7\%A7\%BB\%E6\%B0\%91-50-\%E7\%82\%BA\%E5\%AD\%A9\%E5\%AD\%90\%E6 \%95\%99\%Е8\%82\%B2-\%Е6\%8A\%95\%Е8\%B3\%87\%Е9\%A6\%96\%Е9\%81\%B8\%Е7\%BE\%8E\%Е5\%9C \%8B\%E9\%A6\%99\%E6\%B8\%AF-221248277.html

Mo, J. (2009). The Constitutional Law of the People's Republic of China and Its Development. Columbia Journal of Asian Law, 23(1), 137-184.

National Bureau of Statistics of China. (2010). Quality of Transport Routes. Retrieved October 6, 2012, from http://www.stats.gov.cn/tjsj/ndsj/2010/html/P1605E.HTM

North, D. (1990). Institutions, Institutional Change and Economic Performance. Cambridge Cambridge University Press. http://dx.doi.org/10.1017/CBO9780511808678

North, D. C. (1973). The Rise of the Western World. Cambridge Cambridge University Press. http://dx.doi.org/10.1017/CBO9780511819438

Osman, R. H., Alexiou, C., \& Tsaliki, P. (2011). The Role of Institutions in Economic Development: Evidence from 27 Sub-Saharan African Countries. International Journal of Social Economics, 39(1), 142-160.

Park, W. G., \& Ginarte, J. C. (1997). Intellectual Property Rights and Economic Growth. Contemporary Economic Policy, 15(3), 51-61. http://dx.doi.org/10.1111/j.1465-7287.1997.tb00477.x

Peerenboom, R. (2002). China's Long March Toward Rule of Law. Cambridge, Cambridge Univeristy Press. http://dx.doi.org/10.1017/CBO9780511493737

Peerenboom, R. (2007). China Modernizes: Threat to the West or Model for the Rest? New York, Oxford University Press.

Posner, R. A. (1998). Creating a Legal Framework for Economic Development. The World Bank Research Observer, 13(1), 1-11. http://dx.doi.org/10.1093/wbro/13.1.1

Potter, P. B. (1999). Chinese Legal System: Continuing Commitment to the Primacy of State Power. The China Quarterly, 159, 673-683. http://dx.doi.org/10.1017/S0305741000003428

Priest, E. (2006 ). Future of Music and Film Piracy in China. Berkeley Technology Law Journal, 21, 795-871.

Pye, L. W. (1992). Chinese Negotiating Style, Commercial Approaches and Cultural Principles. Westport, Quorum Books.

Shen, M., \& Wang, Y. (2009). Litigating Economic Disputes in Rural China. China Review, 9(1), 97-121.

Shi, J. (2007). How Chinese Enterprises to Live in Freedom and Competition: Further Integration of the Corporate Law and Competition Law of China with Global Standards. Frontiers of Law in China, 2(2), 224-254. http://dx.doi.org/10.1007/s11463-007-0011-3 
Siu, W. S., \& Liu, Z. C. (2005). Marketing in Chinese Small and Medium Enterprises (SMEs): The State of the Art in a Chinese Socialist Economy. Small Business Economics, 25(4), 333-346. http://dx.doi.org/10.1007/s11187-004-6479-7

$\mathrm{Su}$, C. (2009). The Establishment and Development of the Chinese Economic Legal System in the Past Sixty Years. Columbia Journal of Asian Law, 23(1), 109-136.

Swaleheen, M., \& Stansel, D. (2007). Economic Freedom, Corruption, and Growth. The Cato Journal, 27(3), 343-358.

Tavares, J. (2004). Institutions and Economic Growth in Portugal. Portuguese Economic Journal, 3(1), 49-79. http://dx.doi.org/10.1007/s10258-004-0029-8

Transparency International. (2011). 2011 Corruption Perceptions Index. Retrieved September 2, 2012, from http://cpi.transparency.org/cpi2011/results

Troilo, M., \& Sun, Z. (2010). The Limits of China's Growth. Chinese Management Studies, 4(3), 273-279. http://dx.doi.org/10.1108/17506141011074156

Tsang, W. K. (1998). Can guanxi be a source of sustained competitive advantage for doing business in China? The Academy of Management Executive, 12, 64-74.

Tuuli, M. M., \& Rowlison, S. (2009). Empowerment in Project Teams: A Multilevel Examination of the Job Performance Implications. Construction Management and Economics, 27(5), 473-498. http://dx.doi.org/10.1080/01446190902729713

Wang, L., Huang, J., Chu, X., \& Wang, X. (2010). A Multilevel Study on Antecedents of Manager Voice in $\begin{array}{lllll}\text { Chinese Context. Chinese } & \text { Management }\end{array}$ http://dx.doi.org/10.1108/17506141011074110

Wong, M. (2007). Guanxi and Its Role in Business. Chinese Management Studies, 1(4), 257-276. http://dx.doi.org/10.1108/17506140710828532

Wu, C. (2011). Economic Freedom, Economic Growth, and China. Chinese Economy, 44(5), 104-119. http://dx.doi.org/10.2753/CES1097-1475440506

Wu, Q. (2007). The Making of a Market Economy in China: Transformation of Government Regulation of $\begin{array}{lllll}\text { Market Development. } & \text { European }\end{array}$ http://dx.doi.org/10.1111/j.1468-0386.2007.00394.x

Xu, C. (2011). The Fundamental Institutions of China's Reform and Development. Journal of Economic Literature, 49(4), 1076-1151. http://dx.doi.org/10.1257/jel.49.4.1076

Xu, Y. (2011). An Analysis of the Relationship Between Economic Growth and the Rule of Law: a Lesson from China's Experience. VISTAS Education, Economy and Community The University of West London Journal, 1(1), 36-48.

Yang, M. (1994). Gifts, Favors, and Banquets: the Art of Social Relationships in China. New York, Cornell University Press.

Yu, G. (2009). Adaptive Efficiency and Economic Development in China: The Definition and Enforcement of Property Rights. Australian Journal of Asian Law, 11(1), 82-112.

Yueh, L. (2010). Thirty Years of Legal and Economic Reform in China: Growth, Institutions, and Law. Journal of Chinese Economic and Business Studies, 8(2), 117-132. http://dx.doi.org/10.1080/14765281003750157

Zolkiewski, J. M., \& Feng, J. (2009). Relationship Portfolios and Guanxi in Chinese Business Strategy. Journal of Business \& Industrial Marketing, 27(1), 16-28. http://dx.doi.org/10.1108/08858621211188939

\section{Copyrights}

Copyright for this article is retained by the author(s), with first publication rights granted to the journal.

This is an open-access article distributed under the terms and conditions of the Creative Commons Attribution license (http://creativecommons.org/licenses/by/3.0/). 